Clarke, Matthew ORCID:

https://orcid.org/0000-0003-4693-248X (2018) Education beyond reason and redemption: A detour through the death drive. Pedagogy, Culture and Society.

Downloaded from: http://ray.yorksj.ac.uk/id/eprint/2877/

The version presented here may differ from the published version or version of record. If you intend to cite from the work you are advised to consult the publisher's version: https://www.tandfonline.com/doi/full/10.1080/14681366.2018.1447508

Research at York St John (RaY) is an institutional repository. It supports the principles of open access by making the research outputs of the University available in digital form. Copyright of the items stored in RaY reside with the authors and/or other copyright owners. Users may access full text items free of charge, and may download a copy for private study or non-commercial research. For further reuse terms, see licence terms governing individual outputs. Institutional Repository Policy Statement

\title{
RaY
}

Research at the University of York St John

For more information please contact RaY at ray@yorksj.ac.uk 
Education beyond reason and redemption: A detour through the death drive

\title{
Matthew Clarke
}

School of Education

York St John University

United Kingdom

\begin{abstract}
In contrast to a world that often feels filled with madness and disillusion, education is associated with reason and redemption. Yet from a psychoanalytic perspective, such positivity in relation to education suggests a fantasmatic dimension - a refusal of the inevitable dislocations that prevent life from being harmonious and complete. In this paper, I seek to counter this relentless positivity through an engagement with the negativity of the death drive. Specifically, I provide analyses of two deathly films which can be read as responses to the ills and anxieties of modernity, Peter Weir's Dead Poets Society, and Fritz Lang's M. But whereas Dead Poets Society divides social and educational reality into good and bad, offering the former refuge in romantic individualism, $M$ insists that society as a whole can be viewed as a destructive educational machine - a message that, though hardly comforting, might offer a starting point for rethinking education.
\end{abstract}




\section{Education beyond reason and redemption: A detour through the death drive}

Nature is ambiguous: and to prove its ambiguity it also provides us with the opposite instinct, the death-drive. This conflict, which is not contradictory - as our rational and dialectic mind would like it to be - but oppositional and, as such, non-progressive, unable to perform an optimistic synthesis, takes place in the depths of our soul: in the unfathomable depths, as we all know. But 'authors' have the responsibility to render this conflict explicit and manifest (Pasolini, 1995, p. 269, cited in Vighi 2006, 19).

What is death drive but a failure of death as the negation of life, death that does not manage to negate life but keeps being reinscribed in it, insisting at its core as an excess of life, that in life which is more than life, more than survival, more than finitude, negation as a surplus that gives us access to enjoyment, as opposed to pleasure, an enjoyment beyond the pleasure and the reality principles? (Dolar 2016, 70)

Education - as a signifier, a practice and an institution - is imbued with the positive. We turn to education as a source of optimism, possibility and promise in a world which all too often feels filled with disillusion, despondency and despair. In the dominant social imaginary, education is associated with hope (Halpin 2002), salvation and redemption (Peim 2013, Allen 2014), along with being seen, particularly in the neoliberal era, as a sure-fire path to individual wealth and societal success in the global economic race (Hyslop-Margison and Sears 2006, Pierce 2013). Yet from a psychoanalytic perspective, the insistent drive for positivity in relation to education suggests a fantasmatic dimension - a bracketing out of the inevitable dislocations and disturbances which prevent our lives and our experience from ever being full, harmonious and complete (Glynos and Howarth 2007, Clarke 2012). Yet to read education solely in terms of reason and redemption is to indulge in a form of cruel optimism (Berlant 2011, Moore \& Clarke 2016). It is to deny and disavow the way education serves to sift and sort, classify and categorise, elevating some to lives less ordinary while condemning others to tedious and troublesome toil. In this article I counter this relentless positivity in relation to education with a 'healthy' dose of negativity in order to mobilise 'the power of negative thinking' (Clarke \& Phelan 2015, 2017) and what could be more negative than death?

Indeed, one way of framing the argument of this paper, is that death, framed here in terms of the psychoanalytic notion of death drive, reflects a necessary negativity that offers a salutary and 
sobering counter to positivity, if we are not to lapse into the realms of fantasy. Such lapses can be seen in wider society in phenomena such as belief in the fairness of the world or in eternal life and, in education, by fantasmatic policy tropes promising justice and equality, such as No child left bebind (U.S. Department of Education 2003), Every child matters (Department for Education and Skills (DfES) 2003) and Educational excellence everywhere (Department for Education (DfE) 2016). The following statement from the latter policy document is symptomatic of this wilfully fantasmatic rhetoric: 'Achieving educational excellence everywhere relies on the commitment and dedication of everyone involved in our education system - leaders, teachers, sponsors, members of governing boards, and parents. In the coming years we will work with them to transform the lives of children in every part of this country, for good' $(2016,11)$. As a reality check in response to this utopian rhetoric, it is important to note that, historically, education as a system of social selection and moral training has been far from benign (Allen 2014); and as our economies come to rely less on a domestic skilled workforce as a consequence of the combined effects of offshoring and automation (Blacker 2013, Connell 2013), so the classifying, sifting and sorting work of education is likely to become more brutal. But it is also important to highlight how the over-inflated and fantasmatic rhetoric of education policy, driven by its social utopianism and understandable desire to create a better world, assumes a series of "fits" between the individual and the social, between teaching and learning, between intended and experienced curriculum, whereas psychoanalysis points out that we are all "misfits" and that our fundamental lack of "fit" cannot be rectified or resolved through education or other means (Donald 1992, Ellsworth 1997, Felman 1987).

In order to develop my argument about the way education is haunted by death and the death drive, I draw on two films: Peter Weir's 1989 film, Dead Poets Society, and Fritz Lang's 1931 psychodrama, $M$. Despite their very different settings - 1950s rural New England versus 1930s Berlin - and although only the former involves a school setting, both films have children as central elements and both feature a main character - the new teacher, John Keating, in Dead Poets Society and the elusive serial murderer, Hans Beckert, in $M$ - who appears childlike in many ways. Critically for my analysis, at a time of rising populism in response to social anxiety and economic precarity, both films can be read as responses to the ills of modernity as manifested in their time. Thus, this paper echoes 'a broader insistence that cultural production, such as film, allows us to inhabit alternative narratives in which the past returns and is remembered for its ability to clarify the psycho-social dynamics of the present' (Dyer 2017, 316). 
Perhaps most critically in relation to this paper's title, both films engage with death. Yet despite this, I argue that Dead Poets Society, the suicide of one of Keating's students notwithstanding, evades any full engagement with negativity by projecting it onto the traditional model of education, represented by the established teachers in Welton Academy. This enables newcomer Keating, and the boys that come under his sway, to represent a romanticised version of education as unleashing individuality and in this sense the film's response to the anxieties provoked by modernity is to retreat into a New Age individualism and mysticism (Hentzi 1990). These shortcomings hare highlighted by the contrast with $M$. A much more complex film, $M$ organises and structures the viewer's desire in a way that forces us to recognise the porous line separating our humanity from our monstrosity and to confront our intimate involvement with death and our implication with the death drive. However, before discussing the notion of death in specific relation to these two films, I need to explore the controversial psychoanalytic notion of the death drive and, as we shall see, there is more to death than meets the eye.

\section{Beyond reason and redemption: The death drive}

The tendency towards union - Eros tends to unite - is only ever apprehended in its relation to the contrary tendency, which leads to division, to rupture, to a redispersion... These two tendencies are strictly inseparable (Lacan, 1991, 79).

This is a philosophical, but also an anti-philosophical essay, insofar as it draws on the psychoanalytic thought of Lacan and Freud and, in particular, the controversial notion of the death drive. In making this statement, I am not just referring to the contested boundaries between philosophy and psychoanalysis (Clemens 2013, Samuels 1993), but to the suggestion that anti-philosophical turn in psychoanalysis is marked by the role and place of death in the latter. In developing my argument in this paper, I draw on film which, like tragic drama, helps us to grasp 'the unimaginable limit and the beyond of the symbolic order in its intersection with the category of the real' (Freeland 2013,37) and hence, as my title suggests, to see beyond the familiar tropes of reason and redemption in education.

Freud's notion of the death drive has garnered significant criticism, not least from many of his own followers, on the basis of its allegedly abstract and speculative nature (Boothby 1991, 7-8). It is at very least, a paradoxical concept, not least because of the logical difficulty of representing death, let alone a drive towards death, within life (Boothby 1991, 152, Schuster 2016, 32-33). 
Yet even if there is, in reality, no such thing, it is nonetheless true that 'in the death drive, Freud saw something very profound about the workings of the human mind' (Lear 2000, 62).

The notion of the death drive also suffers from the misreading, common to the notion of drives in general, of being primarily or fundamentally somatic in nature. But while, as Britzman (2009, 89) notes, the drive may involve 'bodily impulses seeking objects, expressing aims and exerting pressure' the death drive is not so much concerned with the body as with the effect of language (more below) on bodily matter: 'it is as cultural subjects that humans are afflicted with the death drive' (Dean 2003, 247, emphasis in the original). In this respect, it is more fruitful to consider the death drive as a creative-destructive force that operates within the folds and disjunctions of life itself:

Instead of picturing the death drive as a substantial force "opposed" to Eros and life, it is more like the knife's edge that separates life from itself, insinuating a gap or dehiscence in its dynamic flux. The death drive is the weird twist or interruption of life that takes away its self-evidence, that suspends the "natural attitude" towards life as continuous flow and variation and vital energy. Never visible as such, Thanatos is what makes life hampered or blocked or resisted from within; it manifests itself through the cracks and fissures that make human life what it is: something not only profoundly at odds with itself but also detached from itself, dead to its own commotion and flow (Schuster 2016, 33).

Freud's original notion of the death drive - a key element of the 'metapsychology' he developed later in his career - reflected a view of human existence as an ongoing struggle between the forces of Eros, the force of life, and Thanatos, the death drive. With the positing of this drive, Freud emphasised the ambivalent, tenuous, conflictual and finite nature of our libidinal relationship to the world, to others and to ourselves, thereby providing one possible explanation for something that has troubled both psychoanalysis and social theory, namely the seemingly endemic nature of violence and destruction in human history (Frosh 2012). The death drive explains why we don't always act in our own self-interest and suggests that we will sacrifice anything - even our own lives - in order to preserve our particular symptom (McGowan 2004, 119). Critically, this reading suggests that the death drive does not represent the obverse or negative side of the healthy and integrated individual's normally positive self but instead undermines the very notion of unitary subject: 'the death drive is not self-will, but a will that 
challenges the integrity of the self (Nobus and Quinn 2005, 148). In this sense, the death drive is fundamental to the psychoanalytic notion of a divided, de-centred subject.

Lacan took Freud's idea of the mind as a site of division and struggle between Eros and Thanatos and reworked it within the triad of the imaginary, symbolic and real registers of the psyche. Here, as with Freud, the death drive is fundamental to the disatisfaction that seems to be part and parcel of human life. But rather than stemming from the conflict between individual and social being, this disatisfaction arises as a result of the split, incomplete nature of human being.

The malaise at the heart of life is not caused in a simplistic one to one way by psychic conflict coming from the clash of superego dicta with id strivings. Nor does it come from identifications with bad parents, or from life frustrations - sexual or otherwise. The malaise is an indestructible inertia in unconscious desire that organises all normative life around the fault or flaw of a sexual unrelation... Two cannot be one. Love does not stop the malaise. A certain unhappiness is the human norm (Ragland, 1995, p. 103).

The death drive names this malaise at the heart of life - a malaise which fantasy repeatedly and compulsively strives to screen or mask through illusions of harmony and completeness and which language continually seeks to fill with ideals and meanings. The desire for oneness is typically interpreted in Oedipal terms in Freudian theory; but for Lacan, there is no natural biological structure to the desire for oneness. Instead, Lacan recasts the Oedipal myth as a lifelong quest for the lost jouissance of being whole. This quest is initiated by the (unconscious) realisation of our separate existence in relation to the (m)other or primary carer, who is not All, and later by (unconscious) recognition of the lack or void in the big Other of the social, symbolic order.

In this reading, the death drive resists and undermines the tendency of the imaginary register the domain of identification and reciprocity but also of alienation and aggression - to create comforting, coherent and stable gestalts. This resistance occurs by way of the destructive violence of the real, as life reminds us that we are not the centre of the universe or masters of our own fates, or through symbolic transformation of the image. The register of the real is commonly associated with violence and destruction; but the linking of the symbolic to the death drive may seem problematic. After all, isn't language the realm of meaning and creativity? 
However, the symbolic is linked to death in various ways, each of which Lacan foregrounded during different stages of his long career (Ragland 1995).

In the first instance, by representing the objects of the real world regardless of the limitations of context, time and place, the symbol represents the absence, or death, of the thing and in this sense, 'the life of the sign is predicated upon the death of the image' (Boothby, 1991, p. 156). In Lacan's words, 'the being of language is the non-being of objects' $(2002,524)$. A key purpose of education is to free students from a reliance on concrete objects and first-hand experience and to enable them to engage with the world in the more abstract ways and distant terms that language and other symbolic systems afford.

In the second instance - a consequence and corollary of the first - Lacan emphasised how the capacity of the sign to signify is tied to its location within the wider network of signifiers rather than its being linked to specific image. The systemic nature of language means that it exceeds the individual's capacity to conceive it as a synchronous whole or to control it, as we witness during verbal slips or unanticipated interpretations of "our" words - when our aptly labelled dis-course goes off-course in relation to our preconceived intentions (Boothby, 1991, p. 257). Here Lacan focused on how, as subjects of language, we are caught up in a vast symbolic system whose meaningfulness derives from the relations among its parts rather than from its correspondence with reality. Yet the essential incompletion and fragmentation of the symbolic that make it so inimical - so murderous - to the holistic and harmonious tendencies of the fantasmatic imaginary are, at the same time, key to its essential creativity and thus to renewal. In similar fashion, like the symbolic realm of language, and like the power of the negative in relation to the positive (Clarke \& Phelan 2015, 2017), the death drive is at once mortifying and revitalizing. This (re)generative aspect of the death drive warrants further exploration.

Santner (2001) sees the death drive as tied up with what he describes as a certain "undeadness" (p. 18) in humanity that is 'generative of a disturbing surplus animation' (19). The death drive, in this reading, concerns not so much at natural, biological cycles of growth and decay, but at this surplus, excessive life (p. 37). Santner argues that a thin line separates our capacity to be animated by this surplus and a defensive shutting-down against its disturbing currents. This "uncanny vitality" (p. 37), as well as the correlative urge to suppress or extinguish it, clearly has implications at the level of the individual and her capacity for creativity. In this regard, it could be argued that modernity's - and for the specific purposes of this paper, modern Education's - 
insistence, on reason and rationality, on consciousness and control, and on performance and positivity (Toulmin 1990) represents a stifling of the very source of the creativity it claims to valorise. In other words, far from being an obstacle to be overcome through education, ironically, were it not for our 'undead' natures and our status as 'misfits', education would not be possible: 'Indeed, if perfect fits were achievable between social relations and psychic reality, between self and language, our subjectivities and our societies would be closed. Completed. Finished. Dead. Nothing to do. No difference. There would be no education. No learning' (Ellsworth, 1997, p. 44). Modern education with its emphasis on reconciling psyche and society, is, by contrast, a denial or refusal of the paradoxical ontology - an ontology whereby consciousness relies on the unconscious just as creation relies on destruction - a world where life itself depends on death, for 'nothing exists except against a supposed background of absence. Nothing exists except insofar as it does not exist' (Lacan 2002, 327).

\section{Film desire and death}

The death drive is excessive to the extent that it exceeds our "natural" view of the positivity of life and in that it incites the subject to seek suffering against its own good and to pursue enjoyment or jouissance - that paradoxically bittersweet, painful-pleasure that comes from transgression beyond the pleasure principle. It is not an exaggeration to say that for Lacan, it is in enjoyment (which is not the same as hedonistic pleasure) that the meaning of life (to the extent that we can talk meaningfully about such a notion) resides, since it is Jouisaance whose absence would render the universe vain' (Lacan 2002, 694). Yet at the same time, paradoxically, he notes, 'Jouissance is what serves no purpose' (Lacan 2000, 3). To this extent, psychoanalysis agrees with existentialism in seeing no ultimate purpose to human life (McGowan 2015, 53).

Cinema stages and relies on enjoyment perhaps more than any other art form. Specifically, films, like theatre, tap into the enjoyment associated with the death drive as they 'put their audiences in touch with a seemingly alien force, 'a tapeworm in our guts', an erotic and deadly drive, behind the beautiful ideals onstage or onscreen and in the Real of the spectator and society' (Pizzato 2004, 84). Dead Poets Society and $M$ both stage encounters with this "alien force" in the shape of confrontations with death. But whereas the latter offers sanctuary from death in the "beautiful ideals" of mysticism and romantic individualism, $M$ brings us face to face with the "erotic and deadly drive" lingering behind any such ideals.

\section{Defiance and death in New England}


In my previous institution, I taught a course for preservice teachers that focused on exploring the professional identities of the teacher. Like many teacher educators, I drew on representations of teachers from films in order to highlight and explore various themes and dominant discourses shaping popular conceptions of the teacher, such as teacher as "hero" or "villain", the teacher as agent of redemption or oppression, and the teacher as outsider (Moore 2004, Dalton 1999). While teaching this course over several years, I was frequently struck by the passion and commitment among many of the students elicited by the figure of John Keating (Robin Williams) from Peter Weir's 1989 film, Dead Poets Society. Its mere mention would elicit excited exclamations of how much 'we love that film?. Such positive responses are not limited to preservice teachers: Guardian writer, Sarfraz Maanzoor, suggests 'Dead Poets Society teaches us to resolve to lead lives of passion and conviction, mindful of the fact that in the story of our lives the script is ours to write' (Manzoor 2011). This enthusiasm is not entirely surprising for, as a number of commentators (e.g. Dettmar 2014) have noted, Dead Poets Society is a deeply seductive, if also, as I shall argue, misleading film.

Though produced at the end of the 1980s, Weir locates his film thirty years earlier in the idyllic setting of rural New England. The 1950s, associated in the popular imagination with stifling conformity, provides the perfect backdrop for a film determined to assert the value of individual passion over the tyranny of tradition. The tension between these themes is depicted visually in the opening scenes as, against the backdrop of a natural world ablaze with fiery autumnal colours, the new school year begins at the aristocratic and conservative Weldon Academy where uniformed boys address their teachers and parents in formal, respectful terms. The new school year also brings the arrival of a new English teacher. Yet John Keating is no stranger to the allboys school and his status as a former pupil serves to connect him to the current crop of students whilst also distancing him from his peers. Indeed, Keating stands out from his fellow teachers in a number of ways, most obviously in being significantly younger, but also in the way he seems to challenge convention at every opportunity. Whistling as he first enters the classroom, he immediately circles back out and, after directing the boys to follow him, has them gather around a display case of alumni photographs. At this point, death enters the scene as Keating points out that the boys in the pictures, who look as fresh faced as their counterparts now gazing upon them, 'are now fertilizing daffodils'. However, rather than delving further into how death gives meaning to life, how as Italian director, Pasolini, puts it, 'only though our death does our life help us to express ourselves' (1995, p. 241, cited in Vighi, 2006, p. 15, italics in original), he urges them to seize the day - carpe diem - and, as he will continually remind them, to live their 
lives with passion, purpose and individuality. Yet what his exhortations misrecognise is how 'individuation is the subtlest form of socialisation' and how 'learning to "think for yourself' is far from thinking by yourself. In practice, it refers to identification with particular symbolic rules and grammars, and thus socialization into particular intellectual and academic subcultures' (Donald 1992, 142). Keating, meanwhile, clearly harbours few if any doubts in relation to his rhetoric and continues to flout convention, by teaching lessons beyond the confines of the classroom and transgressing norms - such as when instructs the boys to rip a chapter from their set text book or has them stand on, and then leap off, his desk.

Keating's interactions with his students continue in the same unorthodox vein, culminating in the scene in which he enthrals his inner circle with an account of the secret society of the film's name:

The Dead Poets were dedicated to sucking the marrow out of life. That's a phrase from Thoreau we would invoke at the beginning of every meeting. A few would gather at the old Indian cave and read from Thoreau, Whitman, Shelley, the biggies - even some of our own verse - and in the enchantment of the moment we'd let poetry work its magic... We were Romantics. We didn't just read poetry, we let it drip from our tongues like honey.

The boys' recreation of the society, however, illustrates that for all his talk of his students finding their own voices, Keating is really just another, albeit more charismatic, version of his more obviously authoritarian colleagues. Indeed, in Žižek’s (1994; cf McGowan, 2004) terms, he represents the obscene, "anal" father, or "Master of Enjoyment" (p. 206), in contrast to the dead-symbolic father represented by his more traditional colleagues. But whereas the traditional symbolic, or oedipal, father prohibits the enjoyment that comes from transgression and insists on stasis - as, for instance, in head teacher, Mr Nolan's, response to Keating's attempts to make the curriculum more engaging: 'Well, John, the curriculum here is set. It's proven. It works. If you question it, what's to stop them from doing the same?' - the new, anal father licenses enjoyment and demands that we enjoy at every moment of our lives. This father leaves no space for privacy, no secret enclave where we might resist the demands of his overbearing presence (McGowan 2004, 46). The demands of the new father are all the harder to resist because, unlike the remote symbolic or oedipal father who commands from above, the anal father positions himself as "one of us" - think of Keating's adolescent antics with the boys - and in this sense seems to embody a more democratic, egalitarian ethos. 
The conflict between the oedipal and anal fathers comes to a tragic conclusion in the suicide of Neil Perry, the leader of the Dead Poets Society, who, encouraged by Keating's repeated exhortations to find one's own individual path, develops a passion for the theatre and acting. Neil's father, who plans for him to attend Harvard and go on to become a doctor, disapproves of what he sees as a dangerous distraction and prohibits any further involvement with this 'acting nonsense'. Caught between the impossibility of reconciling the conflicting demands of the symbolic law represented by his father and the demand for enjoyment represented by Keating, Neil comes to see suicide as his only way out and tragically takes his own life.

In the film's denouement, Keating, having been blamed for Neil's death and subsequently fired, comes into the classroom to clear out his things. Mr Nolan is now reintroducing the boys to traditional English teaching, but as Keating departs he is given a sort of standing ovation as one by one half the boys in the class mount their desks to offer a final salute, 'Oh Captain, My Captain'. Is this a sign that the anal father has won out over the oedipal father or merely a gesture of compensation for the betrayal of the former, offering confirmation of the victory of the latter (many of the boys denounced him after Neil's suicide)? Will the boys remain true to Keating's romantic vision or will they go on to lead the traditional conservative lives the school is intended to prepare them for? Of course, we can't know - this is, after all, a work of fiction but the film's closing scene, in which Keating is positioned centre-stage as the wronged victim, and in which Neil's tragic end quickly fades into the background, suggests a refusal to tarry with the negativity of the death drive and a corollary insistence on subordinating it to Hollywood's beloved trope of the teacher as heroic individual. The film thus performs the 'optimistic synthesis' that Pasolini, in this essay's epigraph, warns against, thereby celebrating education as a source of redemption.

Dead Poets Society presents a vision of education that is beyond the dry, didactic version of reason represented by the traditional father figure of Nolan and the other teachers; but rather than supplementing reason with embodied response and affective engagement, the film merely replaces a desiccated version of reason by an equally unsatisfactory romanticism, based purely on individual passion and one's emotional response to texts. What the film misses is the possibility that the alternative to a pedagogy built around decontextualized facts and information include, not just personal expression but, engagement with ideas that are inevitably suffused with desire and affect. However, the film's romantic vision of education is presented not only as an 
alternative to rationality and reason; it also offers a source of redemption - as a repository for the realisation of hope and fulfilment - a message underscored in the concluding scene as the boys stand on their desks to salute Keating and the vision of education he has presented. In this final moment of affirmation, pain, death and Neil's suicide are sublimated through the boys' solidarity with each other and their common identification with Keating, their spiritual leader.

This analysis - and, of course, this is just one analysis and, like any film, Dead Poets Society is polysemic and open to multiple, divergent readings - suggests that, for all its apparent concern with individualism in the face of stifling conformity, Dead Poets Society is a deeply conservative film to the extent that the boys replace submission to tradition with compliance to rebellious individualism, thereby undermining the film's pretensions to radicalness. The film seems to divide the world into two opposing groups, conforming traditionalists versus individualists, but, as reflected in the collective defiance of the final scene, the latter end up resembling the former in their celebration of the benign authority of the (new) father.

\section{Mania and murder in Berlin}

If death only makes its full appearance late in the day in Dead Poets Society, it confronts the audience early on in $M$. Indeed death assumes centre stage in the film, attributable no doubt, at least in part, to the context of its production in the traumatic years of the Weimar republic in the aftermath of the First World War (Kaes 2009). Yet while Fritz Lang's film may seem to inhabit a distant bygone era, it is salutary to note a number of parallels with the contemporary moment. Such parallels include social anxieties, stemming from economic crisis and expanding urban populations and coalescing in debates about the need for surveillance and the growth of right wing populism. Additionally, in its depiction of the moral panic provoked by the child serial murders - something echoed in contemporary characterizations of the world as replete with risk, danger, threat and anxiety (Cree, Clapton, and Smith 2016) - the film connects with today's concerns about the threats posed to childhood innocence by virtual and online predators that stalk educational and urban spaces. Likewise, the contemporary paranoia about social fragmentation, economic demise and extremist threats that fuels many of the absurdities and dysfunctions of today's education (Sandlin \& Wallin, 2018) find echoes in the film's depiction of the mania and paranoia wreaked on the social body by a serial child killer in Berlin. $M$, however, like so many cultural productions of the Weimar Republic, $M$ is specifically pervaded by the traumas of the First World War, haunted by the banal, industrial-scale, slaughter whereby death seeped into everyday life, undermining the hitherto dominant and optimistic Enlightenment 
model of rationality, reason, progress and education (Freeman 2004). Critically for this paper, the film "records those deep structures of order and disorder which constitute a society in crisis" (Kaes 2000, 9), reminding us that education and pedagogy exceed the limits of school and are intimately entangled with wider culture and society.

Specifically, the film is structured around a number of fundamental antagonisms, which it sustains rather than resolves, most obviously that between the murderer and his pursuers and, within this latter group, between the police and the underworld - the combined forces of the criminals and the beggars. Linking these disparate groups and forces is death, an ever-present yet never directly depicted player, pervading the film as an absent presence. A masterclass in studied ambiguity and ambivalence (Gunning 2000), $M$ can thus be read as an inquiry into the paradoxical 'impossibility of representation that is intrinsic to death' (Freeman 2004) and, beyond this, into the limits of representation as such and the possibilities of non-objective, nonrepresentational representation, as part of a search for 'the truth beyond the reasonable' (Rivette, 1557, p. 140, cited in Vighi 2012, 122). This has implications, as we shall see, for how we conceive of and think about education and the possibilities within it to give voice to the nonsubmissive and non-totalisable impulses of desire, enjoyment and the unconscious.

The film also connects with education in relation to the vision it presents of an indexicalised and textualised urban world. Most obviously this is reflected in the M of film's title, imprinted in chalk by a beggar on the back of Hans Beckert in order to mark him as the murderer. But the letter also suggests a number of central themes of the film, including, in addition to murder and murderer, mothers, mobilisation, mania, crowds (massen in German) and power (macht in German). In addition, the film also contains many other scenes of encoding and decoding impressions and traces, including handprints, fingerprints, graphologists, facsimile prints, newspapers, signatures, handwriting, serialised novels, typewriters, written documents, posters and more - 'the film, in short, continually displays the realia of writing' (Gellen 2015, 425). This is not just an interesting curiosity in the film but offers a commentary on how identity operates in modern society as something cold, external, objective and impersonal - determined less by mental or emotional states than by the physical traces we leave behind (Gellen, 2015, p. 426). It doesn't take much imagination to see parallels with the way students in contemporary education systems are reduced to test scores and exam results, or the way schools as social institutions are reduced to their ratings by inspection bodies. Indeed, while it may not be explicitly concerned with education and schools, the film could be seen as presenting an early, prototypical model of 
the totally pedagogised society (Bernstein, 2001; Singh, 2002). Such a society involves 'symbolic control' in the form of "the direct application of specialized discourses entailed in the shaping, evaluating, regulating and distributing forms of consciousness, disposition, desire and relation, intrinsic to the control of individuals or groups" (Bernstein, 2001, 30). As noted above, M devotes considerable attention to such specialised discourses as when, for instance, we are presented with scenes in which dactylographers and graphologists are shown engaged in detailed indexical work. Thus, while the film in one sense focuses on the individual criminal, Hans Beckert, Lang also suggests that the techniques for identifying marginalised or stigmatised individuals extend to all members of society, each of whom is a potential deviant or criminal and each of whom must therefore be identified and classified through the indexical techniques and investigative principles that constitute symbolic control in the modern era and that contemporary education systems have distilled to a fine art.

$M$ opens with a prolonged moment of black space accompanied only by a resonating gongsomething that would have been associated by contemporaries with the marking of the hour on radio and elsewhere. Later in the film, multiple close-ups of pocket watches and clocks signal the importance of synchronization and highlight the threat to order posed by a malfunctioning part. Reduced to the bare essentials of the medium, the film's minimalist opening “introduces a highly controlled, richly self-reflexive and fully artificial universe in which nothing is left to chance except death" (Kaes 2000, 9). This "scene" can be read as non-figurative reference to death, serving as a pre-cursor for the way death will be a pervasive, but "out of field", absent presence in the film. This moment of darkness is slowly penetrated by the sound of group of children playing an elimination game in the courtyard - a sort of inverse panopticon, visible on all sides from the buildings which surround it - of a tenement block in Berlin. We hear a faint voice in the darkness but can't see anyone. The "acousmatic" use of sound here - a technique that is subsequently repeated with equally eerie effects in relation to the murderer's off-screen whistling - has the uncanny effect of interpellating the viewer as the intended audience, thereby involving us into the drama (Kaes 2000,10). The black screen slowly dissolves to reveal a circle of children, with one girl in the middle, her arms moving mechanically like the hands of a clock, repeating a chant that continues the preoccupation with time: 'Just you wait, it won't be long. The man in black will soon be here. With his cleaver's blade so true. He'll make mincemeat out of you! You're out!'. Mimicking the effects of the serial killer, and coldly recorded by the roving eye of the camera, which looks down from above, 'rhyme (not reason) decides who will be next'

\footnotetext{
${ }^{1}$ Michel Chion's (1994) term for a sound whose source is not initially revealed.
} 
(Kaes 2000,11). Death has penetrated the tenement courtyard reminding us that there are no safe spaces.

The camera pans up to the first floor of the apartment building, passing over two rectangular and coffin-like rubbish bins that trigger an unconscious association between the children, murder and refuse (Kaes 2000,11). A woman carrying a basket of laundry, presumably one of the children's mothers, emerges from a staircase to lean over the railing and chastise them: 'I told you to stop singing that awful song! Didn't you hear me? That same cursed song over and over!'. Whereas the children are preparing for the appearance of death, the adults seek to repress this awareness. The separation of the mothers (there are no fathers in this scene) from their children is reflected in the railing which cuts across the picture and in the way the children (off-screen) ignore her command and, after a few seconds silence, resume the chant. But division and conflict permeate the entire film and other examples can easily be identified. For instance, while Mrs Beckmann, the mother of the film's first victim Elsie Beckmann, anxiously awaits the return of her daughter from school - unaware, unlike the viewer, that Elsie is already in the murderer's hands - a salesman rings the bell of the Beckmann apartment, delivering the latest instalment of a 'thrilling, stimulating, sensational' crime serial. 'Serial killing and serial fiction echo each other with cruel irony' (Kaes 2000, 28), as Mrs Beckmann - like us the film's audience - becomes a unwitting participant in a society that feeds on crime and is capable of deriving enjoyment from the spectacle of horror and violence.

Following the murder of Elsie Beckmann we are presented with scenes of increasingly frenetic activity on the part of the police as they hunt high and low but to no avail for traces of the murderer. Eventually Berlin's criminal fraternity take matters into their own hands and organize for the city's beggars to provide continuous observation of the murderer, Hans Beckert. In another exposure of social contradiction, the thoroughness the beggars are able to bring to this challenge, reflects the pervasive presence of poverty in the city but also exposes the incapacity of the police to fulfil their role of protecting society despite their embodiment of rationality, skepticism and methodological rigour. Meanwhile the poisoned mood and paranoid reactions of the public ('anyone's neighbour can be the murderer') reminds us of how reason is haunted by unreason and how efforts to expose the whole social body to rational knowledge inevitably fall short of their aims when confronted with the primal forces of fear, hysteria and paranoia. 
Society is not the only site of conflict in the film. The child murderer, Hans Beckert, masterfully portrayed by Peter Lorre, himself embodies the fundamental antagonism that manifests itself in the conflictual nature of the unconscious. In one of the most chilling scenes, he gazes at himself in the bathroom mirror in his apartment and uses his fingers to pull the corners of his mouth down, while his eyes bulge, transforming his child-like face from its previously smug, if narcissistic, self-contemplation, into the mask of a monster. But the audience's desire is also divided between, on the one hand, our natural sympathy with the children and the those seeking to protect them and, on the other hand, Beckert as the only character truly individualized in the film (McGowan 2015, 82). The alignment of our desire and our sympathy with Beckert reaches its peak as, his hitherto shadowy and illusive presence now caught in the full gaze of the camera and the Other, he articulates the trauma of his inner conflict in a desperate speech before the angry and hostile kangaroo court assembled by the criminals at the end of the film:

I can't help myself? I have no control over this, this evil thing inside of me, the fire, the voices, the torment! ... It's there all the time, driving me out to wander the streets, following me, silently, but I can feel it there. It's me, pursuing myself! I want to escape, to escape from myself? But it's impossible. I can't escape, I have to obey it. I have to run, run... endless streets. I want to escape, to get away! And I'm pursued by ghosts. Ghosts of mothers and of those children... they never leave me. They are always there... always, always, always!, except when I do it, when I... Then I can't remember anything. And afterwards I see those posters and read what I've done, and read, and read... did I do that? But I can't remember anything about it! But who will believe me? Who knows what it's like to be me? How I'm forced to act... how I must, must... don't want to, must! Don't want to, but must!

This powerful, tormented speech embodies a personal, human sense of identity and thus offers a stark contrast to the objective, impersonal indexical signification of identity noted above (Gellen, 2015, p. 428). Like the recruits in the First World War, who lose whichever way they choose, who must either kill or be killed ${ }^{2}$ and whose plight led Freud to articulate the death drive as a force in human affairs, Beckert is caught in a double bind. The psychic torment is evident in Beckert's struggle to name forces ("this evil thing", "the fire", "the voices") that defy words, exacerbated by the camera's close focus on Peter Lorre's tortured expression and wild gestures,

2 Lang's notebooks suggest he considered inserting a flashback to the trenches here to concretise this allusion (Kaes, 2009, p. 209). 
provides a powerful cinematic rendering of the status we all share as beings who don't and can't fully coincide with ourselves. But critically, the intense focus on Beckert's torment has the effect of engendering sympathy and understanding from the viewer by aligning our desire with Beckert's predicament - and against the angry mob baying for his blood - an alignment embodied in the close-up shots of the faces of some of the criminals and beggars nodding empathetically during the speech. At this moment, the spectator encounters the death drive and the split nature of human being. We are confronted with the ineliminable dimension of social antagonism as we, like the assembled gathering of criminals and beggars, are humbled by the plight of the deviant, the outcast, the failure, in whom we see our own disavowed contradictions reflected. For don't all of us, at some points, recognize our 'misfit' nature and, like Beckert, ask, 'Who will believe me? Who knows what it is like to be me?'? This suggests, as Taubman urges, that 'teachers, when they listen to students' questions or responses, might consider or gently raise the more pressing existential questions behind these and relate them back to curriculum. Who am I to others? What do they want from me or of me? These might be some of the questions around which an academically rich curriculum could be shaped, one which does not silence the unconscious' $(2012,53)$.

By confronting us with such questions, unlike Dead Poets Society, which offers us the (false) consolation of heroic individualism, and by highlighting, rather than shying away from or masking, the split nature of the subject and the irreconcilability of the claims of the individual and those of justice, $M$ forces us to confront the antagonism, conflict and contradiction at work in ourselves and in wider society and, in particular, to recognise the dark, destructive forces that lurk within our psyches alongside the more benign, altruistic impulses and capacities that we typically celebrate in education. Returning to Pasolini's words above, if Dead Poets Society enacts an 'optimistic synthesis', $M$ keeps our attention focused on the inescapability of social and psychic conflict and encourages us to remain attentive to the questions raised by the unconscious.

\section{Conclusion}

Education, as I argued in the introduction and as the title of this paper suggests, is often seen, and tends to see itself, as a site of reason and a source of individual and social redemption. Regardless of the empirical evidence that suggests that this mode of thought is one of cruel optimism, from a psychanalytic perspective pure positivity is undone at a more fundamental level by the death drive which highlights how violent and destructive desires are folded into our more 
socially acceptable and morally benign aspirations. This paper has argued that cinema has the potential for confronting us with the discomforting complexities of human being and the disturbing insistence of the death drive, which resides within our desires and ambitions and undoes our more 'high-minded' illusions. Yet, like many school films, Dead Poets Society for all the its flirtations with darkness and death, ends up recycling well-worn themes of tradition as constraint and time-honoured tropes of heroic individualism, all the while masking its conservatism - at no time are the boys asked to question the privilege they enjoy or the content, rather than merely the manner in which, they are taught - beneath a superficial and fetishized romanticism. In contrast to Dead Poets Society, with its comfortable distinctions between conformity and individualism, its romantic heroes and demonised villains, $M$, despite predating Dead Poets Society by nearly sixty years, presents a far more modern, monstrous and dehumanising world of discipline, punishment, surveillance, identification and classification as society mobilises against the alien presence inhering within it. Yet like Mrs Beckmann in her enjoyment of serialised murder we are all implicated in what this alien presence represents. Indeed, the intertwining of revulsion and fascination we experience as we watch and listen to Beckert's agony reminds us of the impurity of any identity in the face of our status as traumatised misfits who harbour an "undeadness" within us. This in turn suggests that prolix platitudes of policy will always be undone by the unconscious but insistent operations of violence, death and desire. In other words, $M$ suggests, if we are prepared to listen, that we are all implicated in the destructive social machinery of education. Recognition of this implication, though hardly comforting, might offer a starting point for rethinking education.

\section{References}

Allen, A. 2014. Benign violence: Education in and beyond the age of reason. Basingstoke: Palgrave Macmillan.

Berlant, L. 2011. Cruel optimism. Durham, NC: Duke University Press.

Bernstein, B. 2001. Symbolic control: Issues of empirical description of agencies and agents. International Journal of Social Research Methodology, 4(1), 21-33.

Blacker, D. 2013. The falling rate of learning and the neoliberal endgame. Winchester: Zero Books.

Boothby, R. 1991. Freud as philosopher: Metapsychology after Lacan. New York: Routledge.

Britzman, D. P. 2009. The very thought of education: Psychoanalysis and the impossible professions. Albany, NY: SUNY Press. 
Cavell, S. 1979. The world viewed: Reflections on the ontology of film. Enlarged ed. Cambridge, MA: Harvard University Press.

Chion, M. 1994. Audio-vision: Sound on screen. New York: Columbia University Press.

Clarke, M. 2012. "Talkin' 'bout a revolution: The social, political and fantasmatic logics of education policy." Journal of Education Policy 27 (2):173-191.

Clarke, M, and A Phelan. 2015. "The power of negative thinking in and for teacher education." Power and Education 7 (3):257-271.

Clarke, M, and A Phelan. 2017. Teacher education and the political: The power of negative thinking. London: Routledge.

Clemens, J. 2013. Psychoanalysis is an antiphilosophy. Edinburgh: Edinburgh University Press.

Connell, R. 2013. "The neoliberal cascade and education: An essay on the market agenda and its consequences." Critical Studies in Education 54 (2):99-112.

Cree, V E, G Clapton, and M Smith, eds. 2016. Revisiting moral panics. Britsol: Policy Press.

Dalton, M M. 1999. The Hollywood curriculum: Teachers and teaching in the movies. New York: Peter Lang.

Dean, T. 2003. "Lacan and queer theory." In The Cambridge companion to Lacan, edited by J-M Rabaté, 238-252. Cambridge: Cambridge University Press.

Department for Education (DfE). 2016. Educational excellence everywhere. UK: HMSO.

Department for Education and Skills (DfES). 2003. Every child matters. London: The Stationary Office.

Dettmar, K J H. 2014. "Dead Poets Societyls a terrible defense of the humanities." The Atlantic 19 February:1-13.

Dolar, M. 2016. "Not even: The politics of Oedipus." In Jacques Lacan: Between psychoanalysis and politics, edited by S Tomšič and A Zevnik, 62-71. New York: Routledge.

Donald, J. 1992. Sentimental education: Schooling, popular culture and the regulation of liberty. London: Verso.

Dyer, H. 2017. "Reparation for a violent boyhood: Pedagogies of mourning in Shane Meadow's This is England." Pedagogy, Culture \& Society 25 (3):315-325.

Ellsworth, E. 1997. Teaching positions: Difference, pedagogy and the power or address. New York: Teachers College Press.

Felman, S. 1987. Jacques Lacan and the adventure of insight: Psychoanalysis in contemporary culture. Cambridge, MA: Harvard University Press.

Freeland, C. 2013. Antigone, in her unbearable splendour: New essays on Jacques Lacan's the ethics of psychoanalysis. Albany: SUNY Press. 
Freeman, J. 2004. "The semiosis of death in Lang's M: Film and the limits of representation in the Weimar Republic." Film-Philosophy 8 (1):1-22.

Frosh, S. 2012. A brief introduction to psychoanalytic theory. Basingstoke: Palgrave-Macmillan.

Gellen, K. 2015. "Indexing Identity: Fritz Lang's M." Modernism/modernity 22 (3):425-448.

Glynos, J. 2001. "The grip of ideology: A Lacanian approach to the theory of ideology." Journal of Political Ideologies 6 (2):191-214.

Glynos, J. 2008. "Ideological fantasy at work." Journal of Political Ideologies 13 (3):275-296.

Glynos, J, and D Howarth. 2007. Logics of critical explanation in social and political theory. London: Routledge.

Gunning, T. 2000. The films of Fritz Lang: Allegories of vision and modernity. London: British Film Institute London.

Halpin, D. 2002. Hope and education: The role of the utopian imagination. London: Routledge.

Hentzi, G. 1990. "Peter Weir and the cinema of new age humanism." Film Quarterly 44 (2):2-12.

Hyslop-Margison, E, and A Sears. 2006. Neoliberalism, globalization and human capital learning: Reclaiming education for democratic citizenship. Dordrecht: Springer.

Kaes, A. 2000. M. London: British Film Institute.

Kaes, A. 2009. Shell shock cinema: Weimar culture and the wounds of war. Princenton, NJ: Princeton University Press.

Lacan, J. 1991. The seminar of Jacques Lacan: Book II: The ego in Freud's theory and in the technique of psychoanalysis, 1954-1955 (S. Tomaselli, Trans.). New York: Norton.

Lacan, J. 2000. On feminine sexuality, the limits of love and knowledge: The seminar of Jacques Lacan, Book XX: Encore. (B. Fink, Trans.) London: Norton.

Lacan, J. 2002. Écrits. (B. Fink, Trans.) London: Norton.

Lear, J. 2000. Happiness, death, and the remainder of life. Cambridge, MA: Harvard University Press.

MacCannell, J F. 2006. "More thoughts for the times on war and death: The discourse of captialism in Seminar XVII." In Jacques Lacan and The Other Side of Psychoanalysis: Reflections on Seminar XVII, edited by J Clemens and R Grigg. Durham, NC: Duke University Press.

Manzoor, S. 2011. "My favourite film: Dead Poets Society." The Guardian. Accessed 09/10/2017. https://www.theguardian.com/film/filmblog/2011/nov/21/favourite-film-dead-poetssociety.

McGowan, T. 2004. The end of dissatisfaction? Jacques Lacan and the emerging society of enjoyment. Albany, NY: SUNY Press.

McGowan, T. 2015. Psychoanalytic film theory and The Rules of the Game. London: Bloomsbury. 
Moore, A. 2004. The good teacher: Dominant discourses in teaching and teacher education. London: Routledge.

Moore, A, and M Clarke. 2016. "'Cruel optimism': Teacher attachment to professionalism in an era of performativity." Journal of Education Policy 31 (5):666-677.

Nobus, D, and M Quinn. 2005. Knowing nothing, staying stupid: Elements for a psychoanalytic epistemology. London: Routledge.

Pasolini, P P. 1995. Empirismo eretico. Milan: Garzanti.

Peim, N. 2013. "Education, schooling, Derrida's Marx and democracy: Some fundamental questions." Studies in Philosophy and Education 32 (2):171-187.

Pierce, C. 2013. Education in the age of biocapitalism: Optimizing educational life for a flat world. New York: Palgrave-Macmillan.

Pizzato, M. 2004. "Beauty's eye: Erotic masques of the death drive in Eyes Wide Shut." In Lacan and contemporary film, edited by T McGowan and S Kunkle, 83-109. New York: Other Press.

Ragland, E. 1995. Essays on the pleasures of death: From Freud to Lacan. New York: Routledge.

Rivette, J. 1957. "Le main [The hand]." Cahiers du Cinéma 76 (reprinted in Hillier, J. (Ed.). (1985). Cahiers du Cinéma. The 1950s: Neorealism, Hollywood, New Wave (pp. 140-144). London: BFI).

Samuels, R. 1993. Between philosophy and psychoanalysis: Lacan's reconstruction of Freud. London: Routledge.

Sandlin, J. A., \& Wallin, J. J. (Eds.). (2018). Paranoid pedagogies: Education, culture, and paranoia. Basingstoke: Palgrave Macmillan.

Santner, E. 2001. On the psychotheology of everyday life. Chicago: Chicago University Press.

Schuster, A. 2016. The trouble with pleasure: Deleuze and psychoanalysis. Cambridge MA: The MIT Press.

Singh, P. 2002. Pedagogising knowledge: Bernstein's theory of the pedagogic device. British Journal of Sociology of Education, 23(4), 571-582.

Singh, P. 2015. Performativity and pedagogising knowledge: Globalising educational policy formation, dissemination and enactment. Journal of Education Policy, 30(3), 363-384.

Taubman, P. 2012. Disavowed knowledge: Psychoanalysis, education and teaching. New York: Routledge.

Toulmin, S. 1990. Cosmopolis: The hidden agenda of modernity. Chicago: University of Chicago Press.

U.S. Department of Education. 2003. No child left behind: A parents' guide. Washington D.C.: Author. 
Vighi, F. 2006. Traumatic encounters in Italian film: Locating the cinematic unconscious. Bristol: Intellect Books.

Vighi, F. 2012. Critical theory and film: Rethinking ideology through film noir. New York: Bloomsbury. Žižek, S. 1994. The metastases of enjoyment: Six essays on women and causality. London: Verso. 